\title{
Forest science and technology in Canada: Entering the new millennium ${ }^{1}$
}

\author{
by Carl Winget ${ }^{2}$, Ph.D.
}

Recent reviews of government mandates and restructuring of the forest industry are changing roles and responsibilities in forest management in Canada. Companies are increasingly responsible for operational management while federal and provincial governments are focusing more on forest-related policies and regulations, altering in turn the context for forest research.

The adoption of sustainable development as a policy framework is forging stronger links among policy makers, operational forest managers and researchers. Collaboration is growing among research organizations, often in partnerships with clients, in spite of a more competitive fiscal environment. The need to bring the relevant expertise to bear on the issues of sustainable forest development is reinforcing interaction among biological scientists, economists and social scientists, often through computerized communications and information exchange.

Mechanisms have been established by government to develop a common agenda for forest science and technology by all stakeholders, similar to China's Agenda 21. International agreements such as the UN Framework Convention on Climate Change and its Convention on Biological Diversity are exerting increasing influence and demand for additional scientific and technological information.

\section{Introduction}

Forest science has changed drastically in Canada in recent years, reflecting an even more drastic change in the operating context of the forest sector. Several factors have driven this rapid evolution.

As in many other countries, fiscal restraint has significantly modified the funding and options available to respond to shifting priorities. This has led to a reduction of research capacity in most provinces, a re-structuring of many research agencies and a search for collaborative and partnership approaches to research to maximize return on research investments. Restraint has also favoured regulatory roles for governments with delegation of responsibilities for management implementation to industry, changing the client base for research programs.

Forest management philosophy has shifted from sustained yield to sustainable development. The ever increasing social and political acceptance, nationally and internationally, of that shift has developed concerns in a range of activities from biodiversity to forest practices codes to marketing of forest products. These concerns have, in turn, dictated changes in research priorities, programs and philosophies.

Rapid advances in computer technology have directly affected forest research by both increasing research capacity

\footnotetext{
${ }^{1}$ Presentation to the Price Waterhouse Montréal Forest Industry Conference, 25 November 1997, Montréal, Québec.

${ }^{2}$ Director General, Pacific Forestry Centre, Natural Resources Canada, Canadian Forest Service, 506 West Burnside Road, Victoria, British Columbia, Canada V8Z 1 M5.
}

Les récentes révisions des mandats gouvernementaux et la restructuration de l'industrie forestière modifient les rôles et les responsabilités de l'aménagement forestier au Canada. Les compagnies sont de plus en responsables de la gestion opérationnelle tandis que les gouvernements fédéral et provinciaux se centrent de plus en plus sur les politiques et les règlements reliés aux forêts, ce qui modifient en retour le contexte de la recherche forestière.

L'adoption du développement durable en tant que cadre de travail permet d'établir des liens plus solides entre les concepteurs de politiques, les gestionnaires des opérations forestières et les chercheurs. La collaboration croît entre les organismes de recherche, souvent en partenariat avec les clients, malgré la présence d'un environnement fiscal plus compétitif. La nécessité d'apporter une expertise relevante portant sur les questions de développement forestier durable renforce les interactions entre les chercheurs en biologie, les économistes, les chercheurs en sociologie, souvent par l'entremise de communications et d'échanges d'information par voie informatisée.

Les mécanismes ont été mis en place par le gouvernement pour élaborer un plan commun en science et technologie forestière pour toutes les personnes impliquées, un plan semblable à l'Agenda 21 de la Chine. Les ententes internationales comme la Convention cadre sur le changement climatique des N.-U. et la Convention sur la diversité biologique exercent de plus en plus d'influence et exigent de l'information scientifique et technologique additionnelle.

and by creating new opportunities for research in areas such as remote sensing and decision-support systems. Simultaneously, electronic publishing and distribution of scientific information is transforming the conventional world of libraries and scientific journals by introducing new dimensions of speed and complexity.

Further, national and international accords and agree-

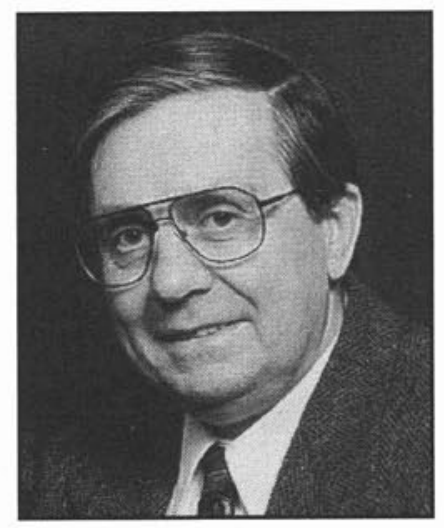
ments and the debate accompanying their development and implementation are demanding new information and imposing new directions on forest science and technology priorities.

This paper briefly explores these conflicting factors and their implications for forest science and technology (S\&T) in Canada which will extend into the new millennium.

\section{Fiscal Restraint}

The struggle to control spending and regain balanced budgets has affected all programs of all levels of government, federal, provincial and municipal, for the past decade. Recently, fiscal restraint has also developed in the forest industry as many companies face difficulties of poor sales and low prices for pulp and paper. The overall result has been for agencies and companies to concentrate on core mandates and functions, to 
divest themselves of peripheral activities and to impose severe budget constraints on the programs and activities retained.

Forest science and technology has not escaped this environment of restraint with important consequences for the framework and structure of the forest research community. In the past decade, forest sector research and development in Canada overall has remained relatively stable, although at a low percentage of sales compared to other forest countries. However, this apparent stability masks a geographic shift in which forest sector $R \& D$ has increased significantly in British Columbia, our Pacific coastal province, and has declined in the federal government and in the other provinces. This has been accompanied by a sharp decline in wood products research. The sawmill industry readily adopts new technology, often imported, but invests little in its development (Binkley and Forgacs 1997).

In the federal government, the reaction to fiscal constraint has been to focus on the roles of policy, international trade and relations and on science and technology. Consequently, jointly funded federal-provincial forest management programs and their science and technology components have been eliminated. Similarly, operational roles traditionally carried out by the federal government, such as forest insect and disease surveys, have become the responsibility of the provincial governments who own most of the forest land. Further, the forest science and technology capacity of the federal government has been significantly reduced.

In their turn, provincial governments are concentrating on their roles as forest landlords with stewardship and regulatory responsibilities. Forest management operations are increasingly delegated to forest companies in return for cutting rights with a variety of funding and stumpage systems to share costs equitably. With the notable exception of British Columbia, Canada's most important forest province, provincial research capacity has also declined. Even BC has seen a reduction in internal capacity offset by a major increase in S\&T funding through a crown corporation with a strong emphasis on short-term applied research and technology development.

Only a few major forest products companies possess forest management research capacity, largely because previous land tenure arrangements didn't require it. Many contribute to and participate in forest engineering, wood products and pulp and paper research, but these areas, especially wood products research as noted above, have also become subject to considerable restraint from all funding sources. The budget constraints currently faced by industry are compounded in the S\&T area by reductions in the forest research community and loss of response capacity even if funds were available.

The consequences of this overall loss of research capacity are not yet apparent, but the outlook is unpromising in a world of fiercely competitive commodity markets for forest products and ever-increasing forest management concerns and constraints.

\section{Sustainable Development}

Sustained yield was the traditional conceptual basis for forest management in Canada and many other countries. Forests were viewed essentially as an economic resource, strongly emphasizing sustained wood supply, industry stability/profitability and sustained employment. Wildlife, especially game species, and fish, notably salmon, were real but secondary concerns. The maintenance of biological productivity and biodiversity was important, but was considered largely in terms of commercial tree species, large mammals, game birds and sports or commercial fisheries. Insects, pathogens and fire were intensively studied, but largely in the context of control of impacts on forest growth and yield. Issues such as conservation and wilderness were dealt with by land-use zoning. A modest proportion of the forest land base was set aside as parks and reserves in which industrial and sports activities were prohibited or severely constrained. Industrial pollution was often viewed as an unfortunate but inevitable cost of economic development. Further, natural resource development was dealt with in the regional or national context with limited concern for international issues other than quarantine and trans-boundary pollution regulations.

In Canada, provinces have jurisdictions over the vast majority of forest lands and grant cutting rights, usually to large forest products companies and for large blocks of land. Provincial forest management agencies and forest industry were, and to a large extent, still are the major clients for forest research. The federal government provided the largest forest management research agency in support of federal policy, revenue maintenance and federal-provincial forest management agreements. Only the three largest provinces, British Columbia, Ontario and Quebec had forest research agencies. Forest engineering and wood products research funding was and is shared by governments and industry. Industry is the principal supporter of pulp and paper research. Some of the principal companies developed internal research capacity. Universities possess an important and varied research capacity largely funded by the federal and provincial governments, but with some industry support through research contracts and funded research chairs.

In recent years, the concept of sustainable development has structured and articulated a body of public opinion, policy and regulation which had accumulated in Canada over two decades or more. Once initiated, its very rapid acceptance as the basis of natural resource management by both federal and provincial governments was far more than a simple extension of sustained yield. It effectively legitimized the integration of economic, environmental and social concerns in all natural resources policy development. It assigned to resource managers the responsibility of responding to all of the political and policy interests across this range of concerns through consultation processes. It accelerated the development of regulatory frameworks, especially forest practices codes and pollution regulations. It drastically broadened the range and complexity of questions needing answers for forest management decision-making. Internationally, it is stimulating the forest convention debate and broadening stewardship responsibilities beyond the national to the global dimension. This has raised the issues of criteria and indicators for monitoring the status of the forest resource and international certification of good forest management practices. It has provided a framework of reference within which global activism and market boycotts influence forest management and pollution regulation decision-making. All of these factors have challenged forest research programs and forced major adaptations to the new policy and priority context.

The shift in the research client base has had far-reaching implications. Even where the same agency has remained a client, its needs have often expanded into new areas. For example, research support to the federal policy function remains as it was in the area of introduced pests and trade, has disappeared as regards 
federal-provincial forest management agreements, and become urgent and imperative in relation to the development of criteria and indicators for international reporting on the state of Canada's forests, especially in the Montreal process.

Clearly, provincial forest agencies and forest industry remain principal clients, but priorities have shifted from traditional silviculture and forest management to support for developing and applying forest practices codes and regulations. The extension of conservation and protection concerns from parks and reserves to all of the forest land base, especially all old growth, is accelerating this trend. The tendency for provinces to emphasize regulatory roles and delegate forest management operations to industry is also leading to a differentiation of research needs. Provinces are more and more seeking information to aid in framing realistic and relevant codes, regulations and procedures with a strong environmental component. In contrast, industry is seeking simplified and cost effective ways to comply with the regulations and maximize both return on investment and growth and yield.

Environmental groups are increasingly recognized as research clients and some have research capability. The relationship is developing slowly, partly because of their suspicions of bias of research organizations towards the interests of their more traditional clients, provinces and industry. Another contributing factor is the fragmentation and disparity of environmental concerns with groups ranging from international organizations with inclusive policies and goals to local single-issue interest groups and association. This makes it very difficult to develop a coherent set of common priorities.

Forest-based communities are also becoming research clients, often indirectly through their involvement in forest landuse planning at the regional level and, in some cases, through community forests. Often, the motivation is to extend forest use to value-added forest products and to diversify use to recreation and tourism to stabilize the community's economic base.

The response of research agencies to these changes is at times simply to shift existing skills and capacity to new areas. For example, the traditional skills of insect and pathogen taxonomists formerly focused on pest monitoring and control programs are now finding a new and much expanded role in studies of biodiversity. The study of nutrition and nutrient cycling, once directed to growth and yield of commercial tree species and treatments such as fertilization, is now concerned with the maintenance of biological productivity for all the components of forest ecosystems.

Often, however, the new priorities demand skills and expertise which are scarce or absent in the existing research community and which take much time and money to develop. Some can only be met by forming research teams uniting diverse skills directed to common goals. These teams often require research management capabilities which are themselves in short supply. Others require networks of expertise and rapid computerized communications linkages among research institutions which span whole nations, or, indeed, the globe.

Computerized support systems for forest management decision-making are among the most demanding of the new needs. They extend from the development of new technology for data acquisition, especially remote sensing, to data bank and information management involving huge data bases, to the integration of that information in expert systems which deal not only with highly complex ecosystems, but with almost equally complex regulatory frameworks such as forest practices codes. Underlying all of this is the driving, urgent need to reach land-use decisions in a reasonable time frame and which consider the interests, often conflicting, of all the interested parties.

The challenges of responding to demands of this kind in the context of severe resource constraints, an aging research community and a real scarcity of critical skills are stimulating to the point of being frightening. Funding constraints and the scarcity of expertise in relation to demand leads to a highly stressed research community experiencing frustration and uncertainty. Conversely, the potential for tremendous advances in forest science and the fact that the knowledge which many of us have spent our entire careers to acquire, is now being applied, often in ways we hadn't foreseen, creates a dynamic, flexible and fastmoving environment which richly rewards initiative and creativity.

\section{Computerization}

The most direct effect of computerization has obviously been to enhance and extend research capacity through the capture, storage, and analysis of data. The transformation of research areas where rapid manipulation of enormous data banks is crucial to both research and the resulting technology is an old story. Remote sensing, especially using satellite imagery, is a prime example. Modelling, especially of biological systems such as nutrient cycling in ecosystems, is another. Forest inventory research and operations are both computer-dependent. The integration of all of these in integrated research, such as in landscape ecology, has added new dimensions to the search for knowledge. In fact, it is difficult to identify research which has not benefited greatly, both in the development of new methodologies and techniques and in the shift of human resources from routine operations in data manipulation to experimental activity. Even classic plant taxonomy uses computerized data bases and literature searches.

Less obvious, but highly important in the mid- to long term, is the impact on the structures and operating modes of research agencies. Fiscal restraint has limited the resources available just as the policy shift to sustainable development has broadened research priorities and emphasized complex, integrated studies. The computerization of research communications has enormously facilitated the development of teams and partnerships, often in the context of "institutes without walls", which has allowed the research community to adapt to the new working environment.

Communications ranging from the humble but extremely effective e-mail to highly sophisticated, very high speed data transmission by fiber optics has allowed physically isolated researchers to dialogue effectively with distant colleagues. Conversely, it has allowed agency research teams to search out and incorporate crucial input from other establishments or individual researchers in their projects at minimal cost. Internet and web technologies have developed a consult-debate-dialogue capacity which in some ways rivals traditional symposia, conferences and seminars. Teleconferencing and video conferencing reinforce these trends, but some level of personal face-to-face contact remains crucial to effective interaction. For most, the new technologies complement, but do not replace more traditional working relationships.

Research management is following researchers into these domains. Within organizations, even at the national level, 
shared planning and budgeting using computerized common office environments are evolving. Reporting and monitoring of progress towards common goals by dispersed researchers and research units are readily achieved. Interagency interactions in research planning and management is increasing at a modest rate in spite of institutional barriers and incompatible planning systems and terminology.

The communication of research results is being completely transformed by computer technology. The initial applications in library cataloguing and literature searches were only a beginning. Word processing was rapidly extended to computer graphics and to desk-top publishing. Conventional hard-copy publishing in scientific journals is rapidly giving way to electronic publishing and new ways to fund journals in a world of electronic information exchange. Further, the internet and web technologies permit instant and wide distribution of contributions from researchers quite outside the universe of the peerreviewed scientific journal which imposes standards of quality in content and format and protects authorship. In fact, this is often occurring outside the overview or control of research managers as well.

The virtual library of electronic publications is rapidly approaching. Its enormous benefits of ease and rapidity of publication and distribution of scientific information at low cost will drive its evolution, but not without a painful transition for both individuals and institutions which find themselves passed over and irrelevant. For those who do adopt the new systems, the continuing problem of first locating relevant information and then evaluating its quality and reliability will attain new dimensions requiring new kinds and levels of personal skills in information acquisition and management.

\section{National and International Issues}

National and international acceptance of sustainable forest development as the appropriate new policy framework has generated discussion and dialogue at many levels. Often stimulated by environmental groups through media pressures, these debates have brought many new issues to the fore. The national forest strategy "Sustainable Forests: A Canadian Commitment" (CCFM 1992) was signed by a coalition of forest stakeholders in 1992 following extensive public consultation. Progress was reviewed in 1994 and the strategy will be revisited and revised as appropriate in 1997. It provides guidance for forest management generally, including science and technology.

The objectives for forest science and technology include fuelling economic development through the development of new products, technology and knowledge; increasing the efficiency of wood utilization; enhancing sustainble forest management practices and supporting policy development at all levels of government. Specific action plans include maintenance of the contribution of forests to the health of the planet; the ability to manage forest ecosystems to maintain their productivity and resilience, development and application of the knowledge and technology needed to achieve sustainable forest management and improvement in industrial competitiveness; a diversification of forest-based industries and an increase in the value derived from the forest; and a heightening of public awareness and knowledge of forests.

In Canada, there is a need for such an evolving strategy including periodic review with broad consultation. While complete consensus can never be reached, it nonetheless provides invaluable context and a significant level of public acceptance for initiatives such as strategic planning by agencies and companies and for public debates such as the ongoing one concerning endangered species legislation.

International conventions and agreements are exerting increasing influence on forest science and technology in Canada. The United Nations Framework Convention on Climate Change is central to research on climate modelling, carbon cycling and atmospheric change including the contribution of wildfires. The Biodiversity Convention drastically altered conventional approaches ranging from species to forest stands to landscapes. As noted earlier, the international search for criteria and indicators to monitor and report on the status of forests globally has generated new research needs, as has the interest in international certification of good forest management practices.

These pressures will continue and evolve as the debate towards an international Convention on Forests proceeds, however fragmented and slow. One inevitable consequence will be the need for new science and technology requiring more international collaboration and partnerships. Canada, a forest nation and steward, welcomes the opportunities that will bring.

\section{References}

Binkley, C.S. and O.L. Forgacs. 1997. Status of forest research and development in Canada. Draft presented to the National Forest Science and Technology Forum, Toronto. Canadian Council of Forest Ministers.

Canadian Council of Forest Ministers. Sustainable Forests: A Canadian Commitment. 1992. 